\title{
E-Government the Department of Investment and Integrated Services City of Palangkaraya
}

\author{
Yunus Praja Panjika*, Budi Suryadi., Mahyuni \\ Master Program of Government Science, Lambung Mangkurat University, Banjarmasin, Indonesia
}

DOI: $10.36348 /$ sjef.2019.v03i11.013 $\quad$ | Received: 09.11.2019| Accepted: 16.11.2019| Published: 19.11 .2019

*Corresponding author: Yunus Praja Panjika

Abstract

This study aims to describe the implementation of E-Government at the Department of Investment and Integrated Services One-Stop city of Palangkaraya in improving Information Technology Development. Qualitative research methods with descriptive type and source of data derived from primary data and secondary data and data collection techniques by researchers are through observation, interviews, and documentation or the collection of supporting documents. Performed data analysis techniques; data reduction, data presentation, and concluding the data sources were obtained. Tests conducted by the researcher's data validity triangulation sources that compare data from interviews and the collection of supporting documents.

Keywords: Electronic Government, technology, and information.

Copyright @ 2019: This is an open-access article distributed under the terms of the Creative Commons Attribution license which permits unrestricted use, distribution, and reproduction in any medium for non-commercial use (NonCommercial, or CC-BY-NC) provided the original author and source are credited.

\section{PRELIMINARY}

Electronic Government is the utilization of information and communication technology for the implementation of efficient and effective governance, with improving public services by providing public facilities so that people easily find information, and creates good governance Government [1]. Applications Electronic Government is a necessity. with the development in the form of Electronic Government application, the Government can optimize the utilization of advances in communications technology and information to eliminate barriers of bureaucratic organization, as well as establish a network management system and work processes that enable government agencies to work in an integrated manner to simplify access to all information and services which should be provided by the Government.

Program Development for Electronic Government itself has also been encouraged by the Government with the advent of Act No. 36 of 1999 on Telecommunications and Law Number 25 Year 2000 on the National Development Program and then both the rules applied by the issued Presidential Decree No. 06 of 2001 on Telematics (Telecommunication, Media and Information Technology), which states that the Government agencies organize and develop the use of Telecommunications, Media and Information Technology within the respective agencies in order to realize good governance, and encourage democracy in Indonesia [2].

The Government's efforts to finalize the implementation of the Electronic Government, the Government issued Law No. 11 the Year 2008 on Information and Electronic Transactions and Government Regulation No. 82 the Year 2012 on the Implementation of Information Systems and Electronic Transactions. This regulation is a cornerstone in the implementation of the Information and Electronic Transaction System provided by the government. The local government in improving the efficiency and effectiveness of the implementation of regional autonomy, need to pay attention to the relationship between Government and intergovernmental arrangement area, potential, and diversity of the area. Aspects of financial relations, public services, utilization of human resources and other resources fairly and equitably implemented. Besides that.

Conditions of application of Electronic Government in the Region today vary greatly existing Local Government agencies adequately prepared in terms of the development of Electronic Government. The government seeking all government agencies and the general public and business people can recognize and implement the Electronic Government in the various activities of dissemination of information, the 
process of service to the Society and others. Given this wide range of service activities carried out can be run more effectively and efficiently and in a cost-effective implementation.

City Government of Palangkaraya own doing Implementation of Electronic Government in the regional work units have been started since 2013, namely the issuance of Regional Regulation of Palangkaraya No. 07 Year 2013 About Transparency of Government and Public participation in which the onepoint regulation is instructed to institutions or work units (SKPD) Palangkaraya City Government for transparency for the regional administration is done through the provision of public information accessibility ie provisioning, administration and issuance of public information by utilizing the facilities and infrastructure of information and Communication Technology [3].

Department of Investment and Integrated Services One-Stop (DPMPTSP) Palangkaraya as government institutions in the city of Palangkaraya authorized to provide licensing services to the public are expected to perform the application of Electronic Government to undertake the development of information technology in the hope of future can provide optimal service to the community. The development of Information Technology in the Government of the more advanced and sophisticated digital era that is characterized by making the opportunities and challenges for the Department of Investment and Integrated Services One-Stop (DPMPTSP) city of Palangkaraya to constantly adapt and improve the quality of His service to the community. Department of Investment and Integrated Services One-Stop (DPMPTSP) city of Palangkaraya has made the development of Electronic Government in the process of licensing services, as follows; einformation, e-citizen, e-service.

E-information, e-citizen, and e-service are how content services developed and implemented by the Department of Investment and Integrated Services One Stop to provide convenient services to businesses in the permitting process. Development of the website's content is part of the modernization process of licensing services that aim to create service processes permit an orderly and transparent achieved following the principle of good governance, namely transparency, participatory, Effective, Efficient, Accountable and Responsive [4, 5].

\section{RESEARCH METHODS}

The approach used is qualitative research. As the name suggests, it is a qualitative research study aimed at describing and analyzing phenomena, events, social activities, attitudes, beliefs, perceptions, thoughts of people individually or in groups. Some descriptions are used to discover and explain the principles that lead to an inference. Qualitative research is inductive, the researchers let the problems arise from the data or left open to interpretation [6]. Data collected by a detailed investigation includes a detailed description of the context in which those records with the results of indepth interviews, as well as the results of the analysis of documents and records.

The reason researchers chose a qualitative research approach aims to understand the phenomenon of what is experienced by the subject of the study such as behavior, perception, motivation, action on the object of research, especially in Research on Application of Electronic Government. Researchers conducted a study using the approach that has two objectives, the first of which, describe and reveal and both describe and explain. Qualitative researchers as a human instrument function set the focus of research, select informants as a source of data, collecting data, assessing data quality, data analysis, interpret the data and make conclusions on the findings [7].

The data source is divided into two primary data and secondary data. Primary data is data obtained by researchers directly (first hand). Secondary data is data obtained by researchers from sources that already exist. The data collection, among others; 1) observation of the object under study to know from the beginning to the end of the activity, 2) key informant interviews using an unstructured interview is an interview conducted freely with ten speakers, 3) documentation in the form of photographs, drawings, regulations, policies, Document Program, as supporting data. Research to strengthen the credibility of the results of observations and interviews conducted by the researchers [8].

Data analysis interactive model by Miles and Huberman selected pattern. to answer the problem formulation or test hypotheses defined in the study. First, the reduction of data so that data recorded carefully and in detail. Second, the presentation of data to be organized and arranged in a pattern of relationships, making it even easier to understand. The third conclusion and verification that findings may be a description or picture of an object that previously was dim or even dark, so that after the investigation became clear. Examination of the validity of such data to obtain the level of confidence concerning how far the truth of the results of research, reveal and clarify the data with facts on the ground. Researchers holding member checks where researchers conducted the process of data obtainable by investigators to data providers [9].

\section{RESULTS AND DISCUSSION}

Application of Electronic Government in the Department of Investment and Integrated Services OneStop city of Palangkaraya to date has been carried out since the year 2014 to 2018. Technology development program and the information are contained in the 2014- 
2018 Work Plan Year in which the presence of this program the Department of Investment and Integrated Services One-Stop city of Palangkaraya to provide maximum service to the community to support the performance of services and information technology licensing. Developing in Electronic Application Government Department of Investment and Integrated Services One-Stop city of Palangkaraya already on a web Presence and Depth of Interaction, to ignite regional website on the internet. The basic information needed by the people featured on the government website and the website already provides the facility of interaction between communities and local governments. The information displayed more varied, such as downloads and communication facilities of public service of the government.

Concept Implementation electronic Government by Nugroho has levels of technological capability that must be met so that the application of Electronic Government can be held in full while the levels that must be met in Implementing Electronic Government are as follows:

1. Web Presence (bring the regional website on the internet, in this stage, the basic information needed by the people featured on the government website).

2. Interaction (Regional websites that provide interaction between the community and local government, in this stage, the information displayed is more varied, such as downloads and communication facilities of public services from the government).

3. Transaction (Website regions besides having interaction facility is equipped with state service transactions).

4. Transformation(In this case the increased government services in an integrated manner, not only the government connects with people but also with other relevant government organizations to intergovernmental).

Application of Electronic Government as a whole is certainly the application of Electronic Government in the Department of Investment and Integrated Services One-Stop city of Palangkaraya must be in accordance with the level of the standard stipulated in the Implementation of Electronic Government, but as you know from our research findings that the application of Electronic Government in the Department of Investment and One-Stop city of Palangkaraya only to the extent of web Presence and Interaction as seen from the focus of planning the implementation of Electronic Government that is conducted by the Department of Investment and Integrated Services One-Stop city of Palangkaraya in
Information Technology Utilization Optimization Program Year 2014-2018 that is:

1. Distribution of online-based Licensing Information

2. Licensing Online

3. Creation of a Public Complaints Service Online

4. Maintenance Information System Network Licensing

Based on existing technology development focus in the Work Plan and Investment Department One Stop Year 2014-2018 that the development of information technology in the Department of Investment and Integrated Services One-Stop city of Palangkaraya focus on the dissemination of information online-based licensing, provision of facilities-based licensing services online, creation of an online complaints service, and maintenance of information systems licensing. Test problems in implementing Electronic Government in the Department of Investment and Integrated Services One Stop has been tested through several indicators that apply to the Elements theory Successful implementation of Electronic Government John F. Kennedy School of Government, namely:

1. Support (Support)

2. capacity (Ability)

3. Value(Benefits)

There are three indicators Elements of Successful Application of the theory of Electronic Government found the problem that led to the adoption of Electronic Government still has not reached the level of application that can perform transactions (transactions) as well as integrated extensively (Transformation) $[10,11]$. The problems faced by the Department of Investment and Integrated Services OneStop city of Palangkaraya first is where the program implementation of Electronic Government conducted by the Department of Investment and Integrated Services One-Stop city of Palangkaraya level technology development only to the extent of Web Presence and Interaction and still the level of technology development in the direction of the Transaction and Transformation.

The problem that the second is the available budget is not in accordance with the budget requirements needed where in theory Elements of a Successful implementation of Electronic Government John F. Kennedy School Of Government at Harvard University that the available budget should be adapted to the needs so that development of information technology made by the Department of Investment and Integrated Services one door city of Palangkaraya can provide superior service to the public in accordance with the Principles of Good Governance. 
Table-1: Budget Work Plan and Budget Ceiling 2014-2018

\begin{tabular}{|c|c|c|}
\hline Year & $\begin{array}{c}\text { Year Work Plan 2014- } \\
\mathbf{2 0 1 8}\end{array}$ & Availability Budget \\
\hline 2014 & Rp. 240,000,000 & Rp. 76 million \\
\hline 2015 & Rp. 270 million & Rp. 85,000,000 \\
\hline 2016 & Rp. 450,000,000 & Rp. 106.891.300 \\
\hline $\mathbf{1}$ & $\mathbf{2}$ & Rp. 103.652.15 \\
\hline 2017 & Rp. 335 million & Rp.98.798.250 \\
\hline 2018 & Rp. 345 million &
\end{tabular}

These three problems faced by the Department of Investment and Integrated Services One-Stop city of Palangkaraya is the lack of support for Standard, Human Resources / Experts in the Department of Investment and Integrated Services One-Stop city of Palangkaraya yet support where to experts who can develop and create applications Management Information systems (MIS) licensing service is still nowhere in theory Elements of a Successful implementation of Electronic Government John F. Kennedy School of Government at Harvard University that Human Resources is one of the indicators that should be considered when doing the program implementation of Electronic Government within a Government agency. The fourth problem which is still a low level of utilization of information technology in the use of public services and their community outreach programs to the community the city of Palangkaraya so that the application of technologies that does not yet maximize.

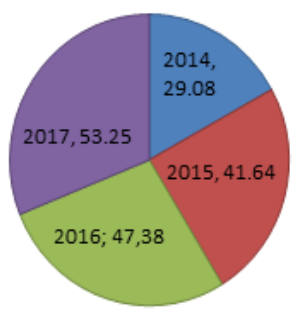

Fig-1: Percentage of Development of Internet Usage in the Public Service Sector by the City of Palangkaraya

It can be seen from the statistical data of the Central Statistics Agency city of Palangkaraya above where since the year 2014 -2017 levels of utilization of information technology in the public service by the people of Palangkaraya still below $70 \%$ so that it can be assumed that the level of technology utilization in the sector of public services Palangkaraya society is still not optimal. Program optimizing the utilization of information technology in the Department of Investment and Integrated Services One-Stop city of Palangkaraya do follow the development of information technology to create information service excellence and disclosure of information to the public in accordance with the principles of good governance such as service that is responsive, effective, efficient, participatory and accountability. It is contained in the government policy in the form of regulations of the Act,

1. Law Number 11 the Year 2008 on Information and Electronic Transactions (ITE).

2. Government Regulation No. 82 the Year 2012 on the Implementation System and Electronic Transactions.

3. Central Kalimantan Provincial Regulation No. 5 of 2013 on Public Information Services.

4. Palangkaraya Regional Regulation No. 7 of 2013 on the Implementation of Government Transparency and Public Participation.

Based on the 4 policy was that the Program Implementation of Electronic Government do follow the policy of the government is the development of information services licensing by provisioning the accessibility of public information in the form of the provision, administration, and issuance of public information by utilizing the facilities and infrastructure of Information Technology and Communication facilitate the public in the licenses. The ability of Infrastructure in the Implementation of the Program Implementation of Electronic Government is in conformity with the needs of where in the Department of Investment and Integrated Services One-Stop city of Palangkaraya own technology devices such as servers themselves and Amenities Computer available are sufficient in order to support the implementation of Electronic Government in the Department of Investment and One-Stop city of Palangkaraya.

Application of Electronic Government at the Department of Investment and Integrated Services OneStop city of Palangkaraya has been implemented in accordance with the program document optimizing the use of information technology 2014-2018 Department of Investment and Integrated Services One-Stop city of Palangkaraya that focuses on online licensing information dissemination, online licensing, and manufacturing services online licensing complaint, as well as the maintenance of information technology networks.

Department of Investment and Integrated Services One-Stop city of Palangkaraya has done Utilization Technology in providing licensing services with a deployment model Electronic Government is in conformity with the state and condition of science and technology development community the city of 
Palangkaraya that models the application of Electronic Government can create Information Systems Licensing Services accessible to the public making it easier for people in the process of licensing services in accordance with the principles of Good Governance that is service transparent, responsive, effective, efficient, participatory, and accountable.

It is assumed that the application of Electronic Government at the Department of Investment and Integrated Services One-Stop city of Palangkaraya only focus on technology development towards Web Presence and Interaction and have not developed the concept of the implementation of Electronic Government to step Transaction and Transformation but the program implementation of Electronic Government implemented by the Department of Investment and One-Stop city of Palangkaraya are in accordance with the principles of good governance, namely licensing information services provided to facilitate the public. According to the research findings uncovered by researchers, there are two indicators of the findings that affect the application of Electronic Government at the Office of Investment and Integrated Services One-Stop city of Palangkaraya outside indicators Elements of Success Electronic Government JFK School of Government, namely:

1. The absence of public education programs related to the utilization of information services technology licensing by the Department of Investment and Integrated Services One-Stop city of Palangkaraya.

2. The absence of relevant Training Program Development and Utilization of Technology to Human Resources (HR) in support of the Application of Electronic Government in the Department of Investment and Integrated Services One-Stop city of Palangkaraya.

Based on the findings beyond the two indicators Elements of Success Electronic Government JFK School of Government in research found by researchers that it is important socialization program to Public and the development of human resource capacity in the form of training programs in human resources quality improvement in utilization as well as the development of technology in the Department of Investment and Integrated Services One-Stop city of Palangkaraya.

\section{CONCLUSION}

Application of Electronic Government that is conducted by the Department of Investment and Integrated Services One-Stop city of Palangkaraya are following the principles of Good Governance that services provided are effective, efficient, responsive, participatory, and accountable. This is illustrated by the application development process that was developed in the implementation of the Electronic Government already reached the stage of a Web Presence and Interaction in which the development of technology in the Application of Electronic Government information services already using the Facility website on the internet, in this stage, the basic information needed by the people featured in government websites and website already provides the facility of information between public services and local government.

Obstacles in the implementation of the Department of Investment and Integrated Services OneStop City is where the support of a program to develop the Application of Electronic Government to the maximum, the Budget provided still does not meet the budget requirements needed, yet their HR experts in developing technology in the implementation of Electronic Government, as well as the still low utilization of technology in accessing public services by the people of the city of Palangkaraya. There are some several important findings in the implementation of Electronic Government that is socialization to the community and the lack of training of human resource development and the availability of the budget is still not in accordance with the needs and limitations of human resources / expertise to support the development of technology in the Department of Investment and Integrated Services One-Stop city of Palangkaraya.

\section{REFERENCES}

1. Indrajit, E. R. (2005). E-Government in Action. Yogyakarta: PT Andi.

2. Widodo, J. (2001). Good Governance: Telaah dari Dimensi Akuntabilitas dan Kontrol Birokrasi Pada Era Desentralisasi dan Otonomi Daerah. Jakarta: Insan Cendekia.

3. Susanto, A., \& wicaksono, W. (2016). Pra Evaluasi Penerapan Electronic Government di Indonesia: Sebuah Analisis Kapabilitas. Jurnal Teknik Informatika.

4. Hardjaloka, L. (2014). Studi Penerapan EGovernment Di Indonesia dan Negara Lainnya Sebagai Solusi Pemberantasan Korupsi Di Sektor Publik. Jurnal Rechtsvinding.

5. Gill, N. K. (2018). Good Governance in India: The Concept and the Practice. Asian Journal of Multidimensional Research (AJMR), 199-206.

6. Bungin, B. (2008). Analisis Data Penelitian Kualitatif. Jakarta: Raja Grafindo Persada.

7. Sugiyono. (2014). Metode Penelitian Kuantitatif Kualitatif dan R\&D. Bandung: Alfabeta.

8. Nasution. (2003). Metode Penelitian Naturalistik Kualitatif. Bandung: Tarsito.

9. Ibrahim. (2015). Metode Penelitian Kualitatif. Bandung: Alfabeta.

10. Oktavia, A. A. (2015). Penerapan Electronic Government Pada Kantor Pelayanan Pajak Pratama Dalam Pemberian Pelayanan Di Kota Bontang. Jurnal Ilmu Pemerintahan.

11. Hasibuan, Z. A. (2018). Langkah-Langkah Strategis dan Taktis Pengembangan E-Government Untuk Pemda. Jurnal Sistem Informasi MTI UI. 